\title{
METALLATION OF ISATIN (2,3-INDOLINEDIONE). X-RAY STRUCTURE AND SOLUTION BEHAVIOR OF BIS(ISATINATO)MERCURY(II)
}

\author{
Angel Garcia-Raso, ${ }^{1}$ Juan J. Fiol, ${ }^{1}$ Elies Molins, ${ }^{2}$ Antonia M. Calafat, ${ }^{3}$ \\ Patricia A. Marzilli, ${ }^{3}$ and Luigi G. Marzilli ${ }^{3}$ \\ 1 Department of Chemistry, Universitat de les Illes Balears, 07071 Palma de Mallorca, Spain \\ 2 Institut de Ciencia de Materials de Barcelona-CSIC, \\ Campus Universitari de Bellaterra, Cerdanyola 08193, Spain \\ 3 Department of Chemistry, Emory University, Atlanta, Georgia 30322, USA
}

\begin{abstract}
The first $\mathrm{X}$-ray structure of an isatin (2,3-indolinedione, isaH) metal complex, bis(isatinato)mercury(II) $\left(\mathrm{C}_{16} \mathrm{H}_{8} \mathrm{~N}_{2} \mathrm{O}_{4} \mathrm{Hg}\right)$ (1), was determined. (1) was obtained from the reaction of isaH with mercury(II) acetate in methanol. Analogously, treatment of sodium saccharinate and mercury(II) acetate in methanol yielded $\mathrm{Hg}$ (saccharinato) ${ }_{2} \cdot 0.5 \mathrm{CH}_{3} \mathrm{OH}$ (3). (1) crystallizes in the monoclinic system, space group $P 21 / a$ with $a=7.299(1) \AA, b=8.192(1) \AA, c=11.601(1) \AA, \beta=$ $105.82(1)^{\circ}, V=667.4 \AA^{3}, Z=2, D_{\text {calc }}=2.452 \mathrm{~g} \mathrm{~cm}^{-3}$, MoK $\alpha$ radiation $(\lambda=0.71073 \AA), \mu=115.5$ $\mathrm{cm}^{-1}, F(000)=460,21(1){ }^{\circ} \mathrm{C}$. The structure was refined on the basis of 2023 observed reflections to $R=0.044$. The two deprotonated, non coplanar isa ligands are trans to each other in a head to tail orientation and bound to the $\mathrm{Hg}$ through the nitrogen in a linear $\mathrm{N}-\mathrm{Hg}-\mathrm{N}$ arrangement. The $\mathrm{Hg}$ atom is at the center of symmetry of the complex and displaced by $0.62 \AA$ from the two planes of the isa ligands $\left(\tau \mathrm{Hg}-\mathrm{N} 1-\mathrm{C} 2-\mathrm{O} 2=-16^{\circ}\right)$. The $\mathrm{Hg}-\mathrm{N}$ bond length is $2.015 \AA$. No $\pi$-aryl-mercury(II)- $\pi$-aryl stacking interaction was observed either in the solid state or in the solution state. The IR, electronic, and ${ }^{1} \mathrm{H}$ and ${ }^{13} \mathrm{C}$ NMR spectral data of (1) and (3) suggest binding of the mercury to the heterocyclic nitrogen, in agreement with the crystal structure determination of (1).
\end{abstract}

\section{INTRODUCTION}

Interactions of heavy metal ions with biomolecules are of interest because of their potential toxic effects. However, the mechanism of action and the biological speciation of toxic metal species are not well defined, although interaction with DNA may be involved. The reversible binding of mercury to DNA has generated some interest, but is still poorly understood at the molecular level. Katz proposed a chain slippage mechanism in which $\mathrm{Hg}(\mathrm{II})$ crosslinked thymine (thyH) nucleobases in opposite strands of the [polyd(AT) $]_{2}$ duplex by forming N3-Hg-N3 bonds, thus disrupting the Watson-Crick hydrogen bonds. ${ }^{1}$ It is widely accepted that mercury binds to the DNA bases, and preferentially to N3 of thymidine as compared to N1 of guanosine. ${ }^{2,3}$ NMR studies of the interaction between $\mathrm{Hg}(\mathrm{II})$ and synthetic oligonucleotides indicate that the thy $\mathrm{N}^{3} \mathrm{H}^{1} \mathrm{H}$ signals disappear upon $\mathrm{Hg}$ (II) complexation, 4,5 supporting Katz's proposal. The propensity of $\mathrm{Hg}(\mathrm{II})$ to bind to highly basic, mononegative $\mathrm{sp}^{2}$ nitrogens could also be manifest in pharmaceuticals or food additives.

Isatin (2,3-indolinedione, isaH) and some of its derivatives, e.g. thiosemicarbazones, possess antiviral activity which is often enhanced upon complexation with metal ions. ${ }^{6-8}$ Although some transition metal complexes with Schiff bases derived from isatin have been studied, 9,10 to our knowledge no metal-isatin crystal structure has been reported. The use of saccharin $(1,2-$ benzisothiazol-3(2H)-one 1,1-dioxide, saccH) as an artificial sweetener is widespread. At high dose levels induces bladder cancer in rats. Some of the saccharin halogeno derivatives are believed to have fungicidal activity, $\mathrm{N}$-acylsaccharins are elastase inhibitors, and the acetic acid derivative is a potent sedative, hypnotic and anticonvulsant. ${ }^{11}$ These two species (Scheme 1) have NH groups that can readily be deprotonated and bind to $\mathrm{Hg}$ (II). They are thus relevant to understanding $\mathrm{Hg}$ (II) binding to DNA. Therefore, the study of the coordination properties of isaH and saccH is of considerable interest. We report the preparation, spectroscopic characterization and the first crystallographic study of an isatin complex, $\mathrm{Hg}($ isa) $2,(1)$. 
<smiles>O=C1Nc2sccc2C1=O</smiles>

isaH<smiles>O=c1[nH]n(S(=O)(=O)c2ccccc2)c(=O)c2ccccc12</smiles>

$\mathrm{saccH}$<smiles>Cc1cn(C)c(=O)[nH]c1=O</smiles>

$\mathrm{H}$

thyH

Scheme 1

\section{MATERIALS AND METHODS}

\section{Analyses and Physical Measurements}

Isatin and mercury(II) acetate were obtained from Merck and used without further purification; sodium saccharinate was from Aldrich. Neutral saccharin was obtained from sodium saccharinate by acidification with $\mathrm{HCl}$ to $\mathrm{pH} 2$. The precipitate was removed by filtration and washed with cold $\mathrm{H}_{2} \mathrm{O}$. Elemental analyses were carried out in a Carlo Erba model 1106 microanalyzer (Centro de Investigación y Desarrollo-CSIC, Barcelona, Spain). Thermogravimetric studies were carried out with a PE TGA-2 thermobalance with oxygen atmosphere (heating rate $5^{\circ} \mathrm{C} / \mathrm{min}$ ). Infrared spectra were recorded in the solid state (KBr pellets) on a PE 683 spectrometer with an infrared data station PE 1600, and the electronic spectra were recorded on a PE 552 spectrophotometer. The 1D NMR spectral measurements of isaH and (1) were made using Gemini 200 and Bruker AMX-300 spectrometers. The $1 \mathrm{D}^{1} \mathrm{H}$ and ${ }^{13} \mathrm{C}$ NMR spectra of sacc, saccH and (3) were carried out on an Omega GN-600 spectrometer. Proton and carbon chemical shifts in DMSO$\mathrm{d}_{6}$ were referenced to internal Me4Si. The 2D NMR experiments were performed on an Omega GN600 spectrometer at $25^{\circ} \mathrm{C}$ without sample spinning. ${ }^{1} \mathrm{H}$-Detected Heteronuclear Multiple Quantum Coherence Spectroscopy (HMQC) ${ }^{12,13}$ : The one-bond ${ }^{1} \mathrm{H}-{ }^{13} \mathrm{C}$ shift correlation spectra resulted from a 256 x 2048 data matrix size with 64, 176, 100, and 100 scans (preceded by 4 dummy scans) per $t_{1}$ value (for $\mathrm{Hg}$ (isa) 2 , isaH, $\mathrm{Hg}\left(\mathrm{sacc}_{2}\right.$, and $\mathrm{Na}$ (sacc), respectively). Predelay was $1.1 \mathrm{~s}$, except for isaH and $\mathrm{Hg}(\mathrm{sacc})_{2}(1.0 \mathrm{~s})$, and $66 \mathrm{~W}(71 \mathrm{~dB})$ of ${ }^{13} \mathrm{C}$ if power and a $31-\mu \mathrm{s} 90^{\circ}{ }^{13} \mathrm{C}$ pulse width were used. A sine bell squared filter was used prior to Fourier transformation in the $t_{2}$ and $t_{1}$ dimensions. ${ }^{1} \mathrm{H}$-Detected Multiple-Bond Heteronuclear Multiple Quantum Coherence Spectroscopy (HMBC) ${ }^{14}$ : The multiple-bond ${ }^{1} \mathrm{H}-{ }^{13} \mathrm{C}$ shift correlation spectra resulted from a $256 \mathrm{x}$ 2048 data matrix size with 160,160,256,208, and 176 scans (preceded by 4 dummy scans) per $t_{1}$ value (for $\mathrm{Hg}$ (isa) $2, \mathrm{Hg}$ (sacc) 2 , isaH, saccH, and $\mathrm{Na}$ (sacc), respectively). Predelay was $1.1 \mathrm{~s}$, except for isaH and $\mathrm{Hg}(\mathrm{sacc})_{2}(1.0 \mathrm{~s})$, and $66 \mathrm{~W}(71 \mathrm{~dB})$ of ${ }^{13} \mathrm{C}$ if power and a $31-\mu \mathrm{s} 90^{\circ}{ }^{13} \mathrm{C}$ pulse width were used. The delay between the first $90^{\circ}{ }^{1} \mathrm{H}$ pulse and the first $90^{\circ} 13 \mathrm{C}$ pulse was $3.3 \mathrm{~ms}$. The delay between the first and the second $90^{\circ}{ }^{13} \mathrm{C}$ pulses was $53.3 \mathrm{~ms}$. A sine bell squared filter was used prior to Fourier transformation in both $t_{1}$ and $t_{2}$ dimensions. The $2 D$ spectra were processed by using the Felix program (Hare Research, Inc.).

\section{Preparative Method}

The mixture of a methanol solution of isaH and a methanol solution of mercury(II) acetate (2:1) afforded an orange precipitate, which was filtered and washed with methanol to give (1). Crystals suitable for X-ray diffraction were obtained from attempts to crystallize mixed-metal $\mathrm{Hg} /$ lanthanide complexes in DMSO/methanol (1/20) in the presence of a 0.5 mole ratio of praseodymium nitrate. ${ }^{15}$ Anal. Calcd for $\mathrm{C}_{16} \mathrm{H}_{8} \mathrm{~N}_{2} \mathrm{O}_{4} \mathrm{Hg}$ : C, 38.98; $\mathrm{H}, 1.62 ; \mathrm{N}, 5.68$. Found: $\mathrm{C}$, 
38.98; H, 1.62; N, 5.67. IR(cm-1): $314 \mathrm{w}, 479 \mathrm{~m}, 490 \mathrm{w}, 690 \mathrm{~m}, 761 \mathrm{~m}, 821 \mathrm{w}, 868 \mathrm{w}, 919 \mathrm{~m}, 972$ $\mathrm{m}, 1092 \mathrm{w}, 1185 \mathrm{w}, 1217 \mathrm{~m}, 1278 \mathrm{~m}, 1313 \mathrm{~m}, 1334 \mathrm{~m}, 1458 \mathrm{~m}, 1596 \mathrm{~s}, 1675 \mathrm{~s}, 1730 \mathrm{~s}$. (s = strong, $m=$ medium, $w=$ weak). $\Lambda_{M}\left(\Omega^{-1} \mathrm{~cm}^{2} \mathrm{~mol}^{-1}\right)=2.4$ for $10^{-3} \mathrm{M}$ solution in DMSO, $20^{\circ} \mathrm{C}$.

An analogous complex, the dihydrate derivative $\mathrm{Hg}(\text { isa) })_{2} \cdot 2 \mathrm{H}_{2} \mathrm{O}(2)$, was obtained as red crystals after mixing methanol solutions of (1) and $\mathrm{Co}\left(\mathrm{NO}_{3}\right)_{2} \cdot 6 \mathrm{H}_{2} \mathrm{O}$ in a 2:1 molar ratio. Unfortunately, the crystals were not suitable for $X$-ray analysis. Anal. Calcd for $\mathrm{C}_{16} \mathrm{H}_{12} \mathrm{~N}_{2} \mathrm{O}_{6} \mathrm{Hg}$ : C, 36.32; H, 2.27; N, 5.30. Found: C, 36.39; H, 1.97; N, 5.31. IR $\left(\mathrm{cm}^{-1}\right)$ : 295w, 315w, 476s, 552m, $647 \mathrm{~m}, 668 \mathrm{~m}, 693 \mathrm{~m}, 758 \mathrm{~s}, 815 \mathrm{w}, 918 \mathrm{~m}, 973 \mathrm{~m}, 1094 \mathrm{~m}, 1190 \mathrm{~m}, 1216 \mathrm{~s}, 1302 \mathrm{~s}, 1333 \mathrm{~m}, 1462 \mathrm{~s}$, 1603s, 1683s, 1727s, 1750s.

$\mathrm{Hg}$ (sacc) $2 \cdot 0.5 \mathrm{CH}_{3} \mathrm{OH}$ (3) was prepared by mixing a methanol solution of sodium saccharinate and a methanol solution of mercury(II) acetate (2:1). A white precipitate that appeared immediately was collected and washed with methanol. A crystalline material was obtained from ethanol and DMSO/methanol (1/20) in the presence of a 0.5 mole ratio of praseodymium nitrate.

TABLE I. Crystal Data and Structure Solution Parameters for (1)

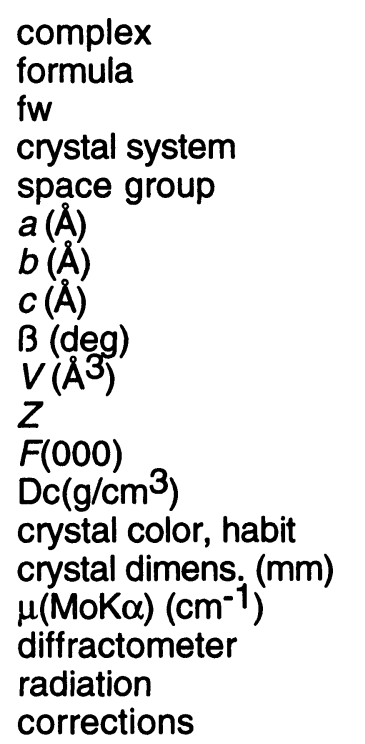

scan type

$2 \theta_{\max }$ range of $h k l$ no. of reflns measured no. of refins included solution hydrogen atoms parameters refined residuals: $R ; R_{w}$ esd of obs. of unit weight convergence, largest shift minimization function least-squares weights instrument instability factor high peak in final diff. map low peak in final diff. map

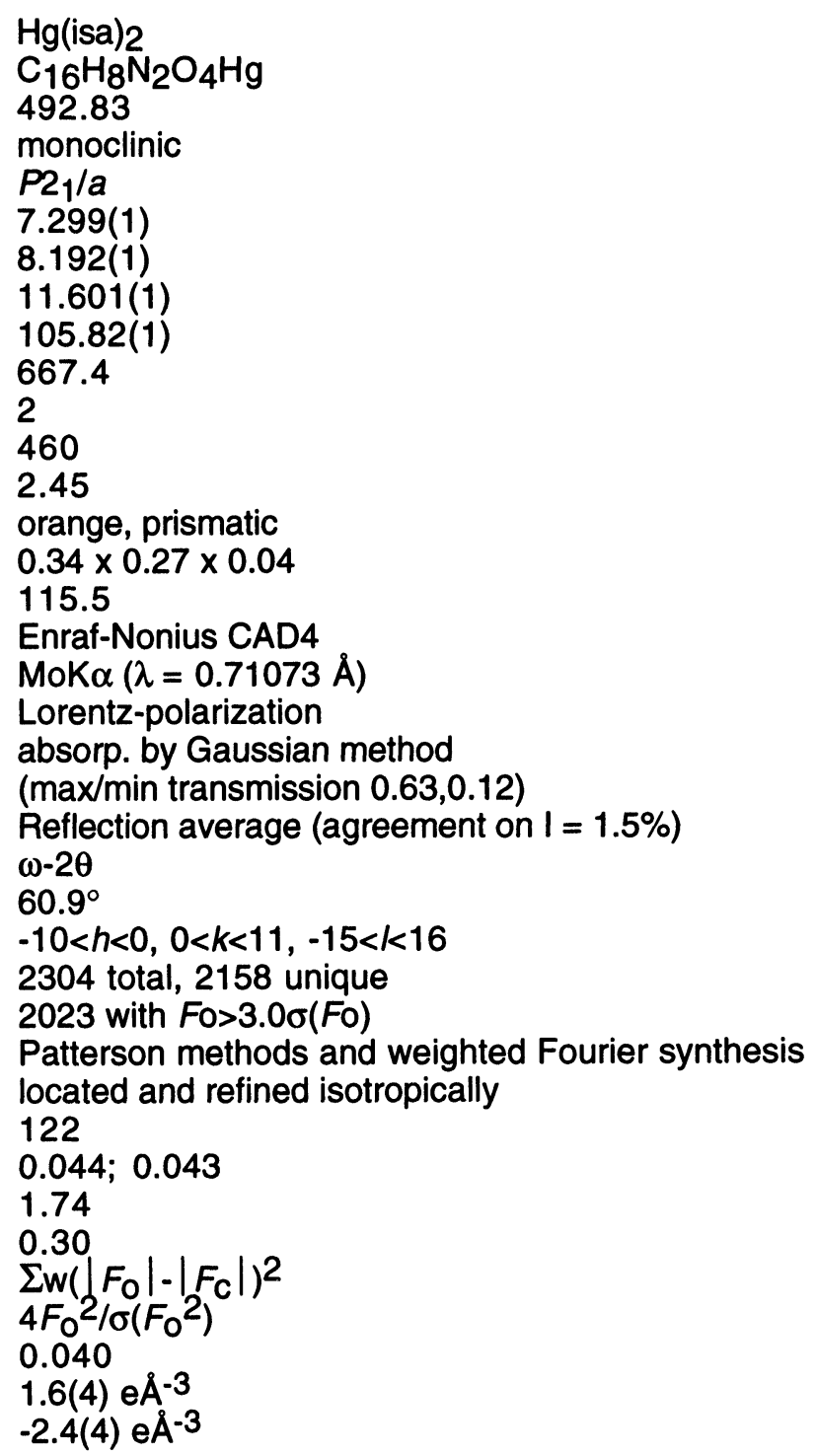


Anal. Calcd for $\mathrm{C}_{14.5} \mathrm{H}_{10} \mathrm{~N}_{2} \mathrm{O}_{6.5} \mathrm{~S}_{2} \mathrm{Hg}$ : C, 29.97; $\mathrm{H}, 1.72 ; \mathrm{N}, 4.82$. Found: $\mathrm{C}, 30.06 ; \mathrm{H}, 1.65 ; \mathrm{N}$, 4.72. IR $\left(\mathrm{cm}^{-1}\right)$ : $352 \mathrm{w}, 402 \mathrm{w}, 462 \mathrm{w}, 533 \mathrm{~m}, 545 \mathrm{~m}, 611 \mathrm{~m}, 637 \mathrm{w}, 680 \mathrm{~m}, 709 \mathrm{w}, 752 \mathrm{~m}, 774 \mathrm{~m}, 794 \mathrm{~m}$, $880 \mathrm{w}, 955 \mathrm{~m}, 965 \mathrm{~m}, 1053 \mathrm{~m}, 1119 \mathrm{~m}, 1129 \mathrm{~m}, 1154 \mathrm{~s}, 1168 \mathrm{~s}, 1254 \mathrm{~s}, 1264 \mathrm{~s}, 1289 \mathrm{~m}, 1335 \mathrm{~m}$, $1350 \mathrm{w}, 1460 \mathrm{w}, 1584 \mathrm{~s}, 1627 \mathrm{~s}, 1659 \mathrm{~m}$. $\Lambda_{\mathrm{M}}\left(\Omega^{-1} \mathrm{~cm}^{2} \mathrm{~mol}^{-1}\right)=5.6$ for $10^{-3} \mathrm{M}$ solution in DMSO, $20^{\circ} \mathrm{C}$.

(1) was thermally stable up to $230{ }^{\circ} \mathrm{C}$. From $230-330{ }^{\circ} \mathrm{C}$, it exhibited a weight loss corresponding to the loss of the two isa moieties per formula unit (Mass loss: Calcd, 59.27\%; Found, $58.33 \%$ ). Further decomposition occurred between $330-530^{\circ} \mathrm{C}$, leaving no residue.

The thermal decomposition of (2) began with a dehydration process at $\sim 120^{\circ} \mathrm{C}$, corresponding to the elimination of two water molecules per formula unit (Mass loss: Calcd, 6.81\%; Found, $6.25 \%$ ). The pyrolytic decomposition of the dehydrated complex occurred in two main steps in a manner similar to that of (1). Again the volatilization of the sample was total.

(3) was thermally stable up to $170^{\circ} \mathrm{C}$. Between this temperature and $200^{\circ} \mathrm{C}$, it exhibited a weight loss corresponding to the loss of the 0.5 molecule of $\mathrm{CH}_{3} \mathrm{OH}$ (Mass loss: Calcd, 2.8\%; Found, $2.8 \%$ ). At $\sim 390^{\circ} \mathrm{C}$, one sacc moiety was lost (Mass loss: Calcd, $32.4 \%$; Found, $31.8 \%$ ).

\section{$X$-Ray Data Collection and Structure Determination}

Table I lists the crystallographic data and details of the X-ray structure analysis for (1). Final positional parameters are listed in Table II.

TABLE II. Positional Parameters and Their Estimated Standard Deviations for (1)

\begin{tabular}{lllll}
\hline atom & \multicolumn{1}{c}{$x$} & \multicolumn{1}{c}{$y$} & \multicolumn{1}{c}{$z$} & $B_{\text {eq }}\left(\AA^{2}\right)$ \\
\hline $\mathrm{Hg}$ & 0 & 0.5 & 0 & $1.809(5)$ \\
$\mathrm{O} 2$ & $0.2777(8)$ & $0.8012(6)$ & $0.1178(5)$ & $3.2(1)$ \\
$\mathrm{O} 3$ & $0.5810(8)$ & $0.7443(7)$ & $0.3437(5)$ & $3.3(1)$ \\
$\mathrm{N} 1$ & $0.2496(8)$ & $0.5201(7)$ & $0.1273(5)$ & $2.08(9)$ \\
$\mathrm{C} 2$ & $0.324(1)$ & $0.6702(8)$ & $0.1663(6)$ & $2.3(1)$ \\
$\mathrm{C} 3$ & $0.4799(9)$ & $0.6399(8)$ & $0.2868(6)$ & $2.1(1)$ \\
$\mathrm{C} 4$ & $0.5746(9)$ & $0.3642(9)$ & $0.4012(6)$ & $2.5(1)$ \\
$\mathrm{C} 5$ & $0.543(1)$ & $0.1961(9)$ & $0.3905(7)$ & $2.9(1)$ \\
$\mathrm{C} 6$ & $0.416(1)$ & $0.1311(8)$ & $0.2864(6)$ & $2.5(1)$ \\
$\mathrm{C} 7$ & $0.3141(9)$ & $0.2310(8)$ & $0.1957(6)$ & $2.0(1)$ \\
$\mathrm{C} 8$ & $0.3415(8)$ & $0.3982(8)$ & $0.2089(6)$ & $2.0(1)$ \\
$\mathrm{C} 9$ & $0.4721(9)$ & $0.4640(8)$ & $0.3084(5)$ & $2.0(1)$ \\
$\mathrm{H} 4$ & $0.66(1)$ & $0.42(1)$ & $0.485(8)$ & $3(2)^{\star}$ \\
$\mathrm{H} 5$ & $0.61(1)$ & $0.12(1)$ & $0.455(8)$ & $4(2)^{\star}$ \\
$\mathrm{H} 6$ & $0.42(1)$ & $0.03(1)$ & $0.281(9)$ & $6(3)^{\star}$ \\
$\mathrm{H} 7$ & $0.24(1)$ & $0.18(1)$ & $0.125(7)$ & $2(2)^{\star}$ \\
\end{tabular}

Starred atoms were refined isotropically. Anisotropically refined atoms are given in the form of the isotropic equivalent displacement parameter defined as:

$$
B_{e q}=\left(8 \pi^{2} / 3\right) \Sigma_{j} \Sigma_{j} \quad U_{i j} \quad a_{i}^{*} \quad a_{j}^{*} \quad \overrightarrow{a_{i}} \cdot \vec{a}_{j}
$$

A flat orange crystal with well-defined faces was selected for the X-ray diffraction experiment and mounted on a glass fiber. Cell parameters were obtained from 22 randomly searched highorder reflections. Once the crystal was oriented, the faces were indexed and accurately measured. Distances among parallel faces were 0.30 [110], 0.27 [110], 0.35 [100] and $0.04 \mathrm{~mm}$ [001]. Data were collected at 294(1) K. Three reflections were measured each hour without significant time decay. In order to account for the high absorption effects, some reflections were measured at each $10^{\circ}$ of $\Psi$ angle. The estimated maximum absorption was $91 \%$. Lorentz and polarization corrections were applied. The best set of non-unique data was averaged $\left(R_{\mathrm{int}}=0.015\right)$, resulting in 2023 
unique reflections. The $\mathrm{Hg}$ atom was located from a Patterson map and the remaining atoms, including hydrogens, appear in successive Fourier syntheses. In addition, several refinement processes were carried out using different sets of data corresponding to different absorption corrections. ${ }^{16}$ The quality of the correction was estimated from the $R$ value at convergence when all atoms were allowed to vibrate isotropically and, especially, by the height of the residual peak close to the $\mathrm{Hg}$ atom in a subsequent difference Fourier synthesis.

Empirical absorption corrections by 'psi scans', by 'Fourier series' or both applied

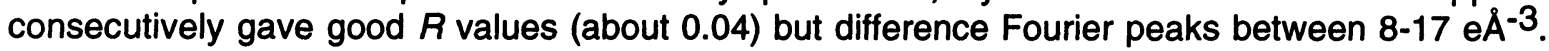
Gaussian absorption correction was applied for different values of the crystal thickness $\delta$ (distance among [001] and [00 $\overline{1}$ ] faces). For $\delta$ values of 40 and $41 \mu \mathrm{m}$, the $R$ value was 0.044 and the residual peak $1.7 \mathrm{e} \AA^{-3}$, whereas for $\delta$ values of 39 and $42 \mu \mathrm{m}, R$ and the residual peak were 0.18 and $10.6 \mathrm{e}^{-3}$, respectively. As expected, a Gaussian correction gave the best results, but only when crystal dimensions were evaluated accurately. Refinement with anisotropic thermal parameters for non- $\mathrm{H}$ atoms and isotropic for $\mathrm{H}$-atoms converged at $R=0.044\left(R_{\mathrm{W}}=0.043, \mathrm{w}=\right.$ $4 F_{0}^{2} / \sigma\left(F_{0}^{2}\right)$ ) using 1326 reflections with $F_{0}>3 \sigma\left(F_{0}\right){ }^{17}$
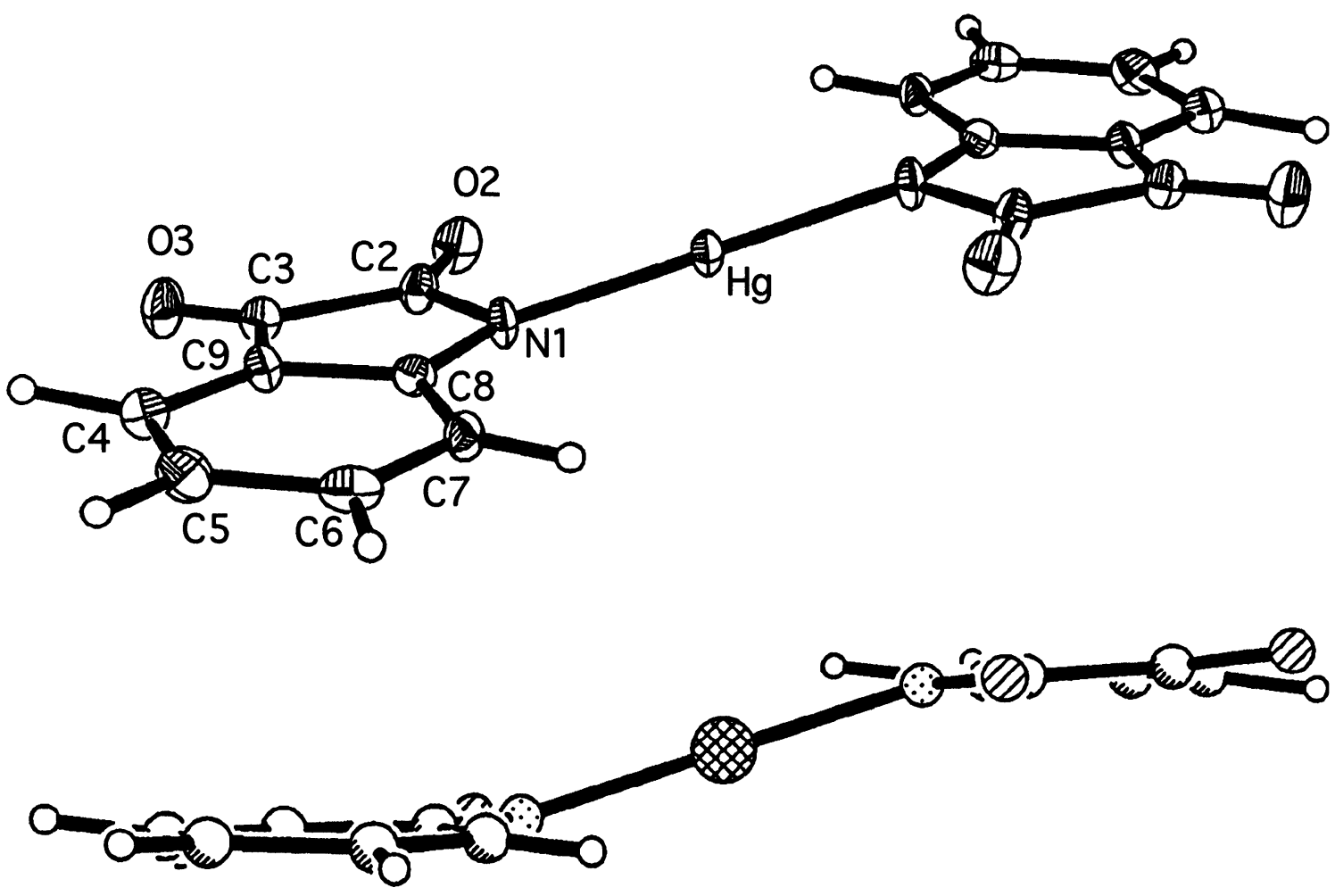

FIGURE 1. Molecular structure of $\mathrm{Hg}$ (isa) $)_{2}$, showing the atom numbering scheme.

\section{RESULTS AND DISCUSSION}

Reaction of isaH and saccH with mercury(II) acetate in methanol yielded the compounds $\mathrm{Hg}$ (isa) 2 (1) and $\mathrm{Hg}(\mathrm{sacc})_{2} \cdot 0.5 \mathrm{CH}_{3} \mathrm{OH}$ (3), respectively. The molecular structure of (1) and the atom numbering scheme are shown in Figure 1. The two deprotonated, non coplanar isatin ligands are trans to each other and bound to the mercury in a head to tail orientation via the heterocyclic nitrogen in a linear $\mathrm{N}-\mathrm{Hg}-\mathrm{N}$ arrangement. The $\mathrm{Hg}-\mathrm{N}$ bond distance $(2.015(5) \AA)$ is similar to previously reported distances in other $\mathrm{Hg}-\mathrm{N}$ (heterocyclic) systems. ${ }^{15,18-20} \mathrm{The} \mathrm{Hg}$ atom is at the center of symmetry of the complex and displaced by $0.62 \AA$ from the two planes of the isa ligands 
(torsion angle $\left.\tau \mathrm{Hg}-\mathrm{N} 1-\mathrm{C} 2-\mathrm{O} 2=-16^{\circ}\right)$. In $\mathrm{Hg}(1-\text { methy) } 2 \text {, (1-methyH }=1-\text { methylthymine })^{20}$ the $\mathrm{Hg}$ atom is also at the center of symmetry of the complex but with the $\mathrm{Hg}$ only $0.3 \AA$ above the thy ring. The Hg-N1-C2 and C2-N1-C8 angles of (1) contract to 120.8(4) and 109.9(5) ${ }^{\circ}$, respectively, and the $\mathrm{Hg}-\mathrm{N} 1-\mathrm{C} 8$ angle enlarges to $127.0(4)^{\circ}$ compared to the corresponding angles in the free isaH moiety. ${ }^{21-23}$ These facts could be related to some distortion of the geometry at $\mathrm{N} 1 \mathrm{upon} \mathrm{Hg}$ complexation, as described previously for a 4-methyl-2-(1H)-quinolone mercury (II) complex. ${ }^{15}$ In contrast, no noticeable distortion at N3 was found in $\mathrm{Hg}(1-\text { methy })_{2}{ }^{20}$ The very long $\mathrm{C} 2-\mathrm{C} 3$ bond $(1.564(9) \AA)$ of (1), also observed in the structure of the free ligand, has been related to nonbonded lone pair-lone pair repulsions in cis-diketones. ${ }^{21}$ Selected bond distances and bond angles are given in Table III.

TABLE III. Selected Bond Lengths and Angles for Compound (1) ${ }^{a}$

Bond Lengths ( $\AA$ )

\begin{tabular}{llllll}
\hline $\mathrm{Hg}$ & $\mathrm{N} 1$ & $2.015(5)$ & $\mathrm{C} 4$ & $\mathrm{H} 4$ & $1.11(9)$ \\
$\mathrm{O} 2$ & $\mathrm{C} 2$ & $1.215(8)$ & $\mathrm{C} 5$ & $\mathrm{C} 6$ & $1.41(1)$ \\
$\mathrm{O} 3$ & $\mathrm{C} 3$ & $1.203(8)$ & $\mathrm{C} 5$ & $\mathrm{H} 5$ & $1.0(1)$ \\
$\mathrm{N} 1$ & $\mathrm{C} 2$ & $1.370(8)$ & $\mathrm{C} 6$ & $\mathrm{C} 7$ & $1.38(1)$ \\
$\mathrm{N} 1$ & $\mathrm{C} 8$ & $1.414(8)$ & $\mathrm{C} 6$ & $\mathrm{H} 6$ & $0.8(1)$ \\
$\mathrm{C} 2$ & $\mathrm{C} 3$ & $1.564(9)$ & $\mathrm{C} 7$ & $\mathrm{C} 8$ & $1.386(8)$ \\
$\mathrm{C} 3$ & $\mathrm{C} 9$ & $1.467(9)$ & $\mathrm{C} 7$ & $\mathrm{H} 7$ & $0.94(7)$ \\
$\mathrm{C} 4$ & $\mathrm{C} 5$ & $1.40(1)$ & $\mathrm{C} 8$ & $\mathrm{C} 9$ & $1.390(8)$ \\
$\mathrm{C} 4$ & $\mathrm{C} 9$ & $1.396(9)$ & & &
\end{tabular}

Bond Angles (deg)

\begin{tabular}{llllllll}
\hline $\mathrm{Hg}$ & $\mathrm{N} 1$ & $\mathrm{C} 2$ & $120.8(4)$ & $\mathrm{C} 6$ & $\mathrm{C} 5$ & $\mathrm{H} 5$ & $120(6)$ \\
$\mathrm{Hg}$ & $\mathrm{N} 1$ & $\mathrm{C} 8$ & $127.0(4)$ & $\mathrm{C} 5$ & $\mathrm{C} 6$ & $\mathrm{C} 7$ & $121.4(6)$ \\
$\mathrm{C} 2$ & $\mathrm{~N} 1$ & $\mathrm{C} 8$ & $109.9(5)$ & $\mathrm{C} 5$ & $\mathrm{C} 6$ & $\mathrm{H} 6$ & $114(8)$ \\
$\mathrm{O} 2$ & $\mathrm{C} 2$ & $\mathrm{~N} 1$ & $127.2(6)$ & $\mathrm{C} 7$ & $\mathrm{C} 6$ & $\mathrm{H} 6$ & $124(8)$ \\
$\mathrm{O} 2$ & $\mathrm{C} 2$ & $\mathrm{C} 3$ & $126.6(6)$ & $\mathrm{C} 6$ & $\mathrm{C} 7$ & $\mathrm{C} 8$ & $118.0(6)$ \\
$\mathrm{N} 1$ & $\mathrm{C} 2$ & $\mathrm{C} 3$ & $106.2(5)$ & $\mathrm{C} 6$ & $\mathrm{C} 7$ & $\mathrm{H} 7$ & $118(4)$ \\
$\mathrm{O} 3$ & $\mathrm{C} 3$ & $\mathrm{C} 2$ & $124.5(6)$ & $\mathrm{C} 8$ & $\mathrm{C} 7$ & $\mathrm{H} 7$ & $124(5)$ \\
$\mathrm{O} 3$ & $\mathrm{C} 3$ & $\mathrm{C} 9$ & $130.6(6)$ & $\mathrm{N} 1$ & $\mathrm{C} 8$ & $\mathrm{C} 7$ & $126.6(6)$ \\
$\mathrm{C} 2$ & $\mathrm{C} 3$ & $\mathrm{C} 9$ & $104.9(5)$ & $\mathrm{N} 1$ & $\mathrm{C} 8$ & $\mathrm{C} 9$ & $112.0(5)$ \\
$\mathrm{C} 5$ & $\mathrm{C} 4$ & $\mathrm{C} 9$ & $118.0(7)$ & $\mathrm{C} 7$ & $\mathrm{C} 8$ & $\mathrm{C} 9$ & $121.4(6)$ \\
$\mathrm{C} 5$ & $\mathrm{C} 4$ & $\mathrm{H} 4$ & $123(5)$ & $\mathrm{C} 3$ & $\mathrm{C} 9$ & $\mathrm{C} 4$ & $132.0(6)$ \\
$\mathrm{C} 9$ & $\mathrm{C} 4$ & $\mathrm{H} 4$ & $118(5)$ & $\mathrm{C} 3$ & $\mathrm{C} 9$ & $\mathrm{C} 8$ & $106.8(5)$ \\
$\mathrm{C} 4$ & $\mathrm{C} 5$ & $\mathrm{C} 6$ & $120.1(7)$ & $\mathrm{C} 4$ & $\mathrm{C} 9$ & $\mathrm{C} 8$ & $121.0(6)$ \\
$\mathrm{C} 4$ & $\mathrm{C} 5$ & $\mathrm{H} 5$ & $120(6)$ & $\mathrm{N} 1$ & $\mathrm{Hg}$ & $\mathrm{N} 1$ & 180 \\
\end{tabular}

a Numbers in parentheses are estimated standard deviations in the least significant digits.

The $\mathrm{Hg}$ (isa) 2 units are linked by hydrogen bond interactions $(\mathrm{O} 2 \ldots \mathrm{H} 6=2.44 \AA)$. This hydrogen bond network seems to play an important role in both the formation of a polymeric chain (Figure 2) and the stabilization of the crystal structure. Roughly speaking, the $\mathrm{Hg}$ atom is in a distorted octahedral environment with two $\mathrm{Hg}-\mathrm{N}$ bonds of $2.015 \AA$ and with two intramolecular and two intermolecular long $\mathrm{Hg}-\mathrm{O}(2)$ contact distances of 3.256 and $2.899 \AA$, respectively. A similar situation was found in $\mathrm{Hg}(1 \text {-methy })_{2}$, where the $\mathrm{Hg}-\mathrm{O}$ contacts were $3.03-3.05 \AA .20$ The $\mathrm{Hg}$ of one $\mathrm{Hg}$ (isa) 2 unit lies between two adjacent $\mathrm{Hg}$ (isa) 2 chains, so $\pi$-aryl-Hg- $\pi$-aryl stacking interactions are not established, in contrast to what occurs in $\mathrm{Hg}(4-\text { methyl-2-(1H)-quinolone })_{2}{ }^{15}$

The infrared spectra of (1) and (3) in the far-IR region to $200 \mathrm{~cm}^{-1}$ were compared with those of the free ligands. Tentative assignments of some bands were made by analogy with similar systems. $7,24,25$ The disappearance of the broad vNH band at $3180 \mathrm{~cm}^{-1}$ for isaH and at $3100 \mathrm{~cm}^{-1}$ 


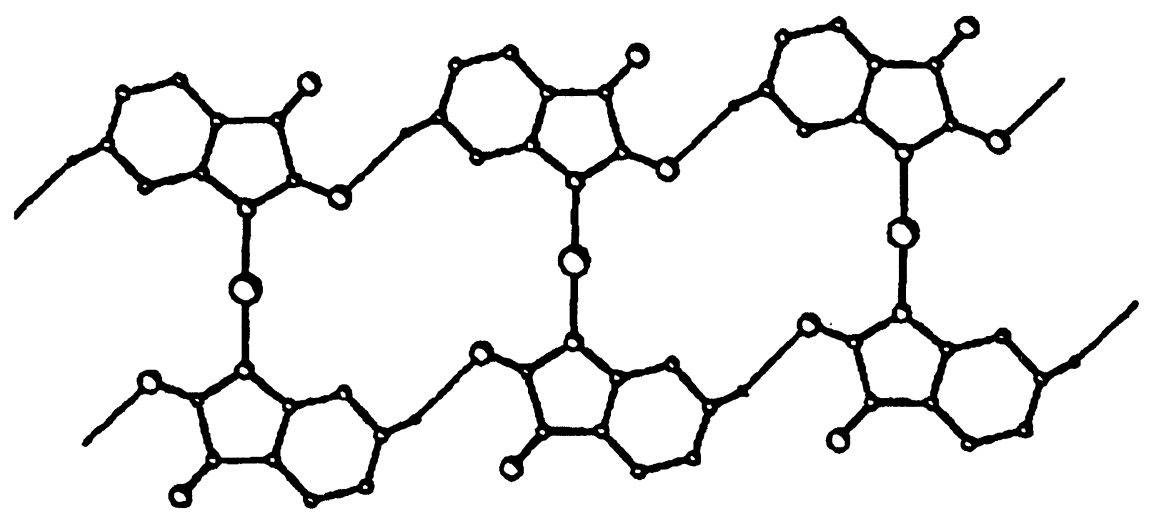

FIGURE 2. Drawing of the linked chains of $\mathrm{Hg}(\text { isa })_{2}$ units along $b$

for saccH suggests involvement of the heterocyclic nitrogen in the bonding in the respective complexes. Furthermore, the $\mathrm{VC}=\mathrm{O}\left(1731 \mathrm{~cm}^{-1}\right)$ band of isaH split into two peaks at 1730 and 1675 $\mathrm{cm}^{-1}$ and decreased in intensity. These changes would be consistent with the participation of the $\mathrm{C}(2)=\mathrm{O}$ group in a hydrogen bond, as indicated by the crystallographic data. Most of the bands of isaH in the $1600-1300 \mathrm{~cm}^{-1}$ region shift to lower frequencies in the spectrum of (1). For (3), the $\mathrm{vC}=\mathrm{O}\left(1720 \mathrm{~cm}^{-1}\right)$ band of saccH split into two peaks at 1642 and $1627 \mathrm{~cm}^{-1}$ and the 1336 and $1178 \mathrm{~cm}^{-1}$ strong bands assignable to $\mathrm{v}_{\mathrm{a}}\left(\mathrm{SO}_{2}\right)$ and $\mathrm{vb}_{\mathrm{b}}\left(\mathrm{SO}_{2}\right)$, respectively, shifted to lower frequencies. This is consistent with a considerable decrease in the bouble-bond character of the $\mathrm{CO}$ and $\mathrm{SO}_{2}$ groups upon coordination.

The electronic spectrum of isaH in DMSO displays bands at $256 \mathrm{~nm}\left(\varepsilon=3.8 \times 10^{3} \mathrm{M}^{-1} \mathrm{~cm}^{-1}\right)$ and $297 \mathrm{~nm}\left(\varepsilon=3.63 \times 10^{3}\right)$ assignable to transitions of the benzene moiety. No changes in these bands were observed upon metal complex formation. In contrast, the characteristic charge-transfer band of the ligand at $418 \mathrm{~nm}\left(\varepsilon=1.07 \times 10^{3}\right)$ red-shifted to $445 \mathrm{~nm}\left(\varepsilon=1.38 \times 10^{3}\right)$ in the spectrum of (1). In the case of $\mathrm{Hg}(\mathrm{sacc})_{2}$, the $\pi \rightarrow \pi^{*}$ transition band $\left(272 \mathrm{~nm}, \varepsilon=1.42 \times 10^{3}\right)$ of the neutral saccharin in DMSO shifts to $256 \mathrm{~nm}\left(\varepsilon=2.4 \times 10^{4}\right)$ upon metal complex formation.

HMBC (Figure 3) and HMQC were used to assign the ${ }^{1} \mathrm{H}$ and ${ }^{13} \mathrm{C}$ NMR spectra of the ligands and the mercury complexes. The ${ }^{1} \mathrm{H}$ and ${ }^{13} \mathrm{C}$ assignments of isatin and $\mathrm{Hg}(\text { isa })_{2}$ in $\mathrm{DMSO} d_{6}$ are shown in Table IV. The nonprotonated carbon resonances of (1) were recognized from the HMQC spectrum and assigned from the HMBC spectrum. The ${ }^{13} \mathrm{C}$ signal at $163.8 \mathrm{ppm}$, with no correlations in the HMBC spectrum, was assigned to C2. In order to complete ${ }^{1} \mathrm{H}$ and ${ }^{13} \mathrm{C}$ assignments, use was made of the fact that for aromatic systems three-bond $\mathrm{J}_{\mathrm{CH}}$ couplings are bigger than two bond couplings. ${ }^{26}$ The doublet at $7.47 \mathrm{ppm}$ with connectivities in the HMBC spectrum to the ${ }^{13} \mathrm{C}$ signals at $138.4,158.3$ and $186.3 \mathrm{ppm}$ was assigned to $\mathrm{H} 4$. $\mathrm{H} 4$ is the only proton that can have three-bond correlations to the two nonprotonated carbon resonances at 158.3 and $186.3 \mathrm{ppm}$. The remaining doublet in the ${ }^{1} \mathrm{H}$ NMR spectrum at $7.38 \mathrm{ppm}$ was then assigned to $\mathrm{H} 7$. $\mathrm{C} 9$ and $\mathrm{C} 5$ were assigned as the signals at 120.4 and $122.2 \mathrm{ppm}$ from their $\mathrm{HMBC}$ correlations to $\mathrm{H} 7$. The triplet at $6.99 \mathrm{ppm}$ was assigned to $\mathrm{H} 5$ from its $\mathrm{HMQC}$ correlation to $\mathrm{C} 5$, and the remaining triplet at $7.59 \mathrm{ppm}$ was assigned to $\mathrm{H} 6$. C8 was assigned as the resonance at 158.3 ppm from its $\mathrm{HMBC}$ correlations to both $\mathrm{H} 4$ and $\mathrm{H} 6$. The remaining nonprotonated ${ }^{13} \mathrm{C}$ signal at $186.3 \mathrm{ppm}$ was assigned to C3. Assignment of the ${ }^{1} \mathrm{H}$ and ${ }^{13} \mathrm{C}$ NMR spectra of isaH, saccH, $\mathrm{Na}$ (sacc)and $\mathrm{Hg}(\mathrm{sacc})_{2}$ in DMSO- $d_{6}$ was done in an analogous way (Table IV).

Upon complexation of both isaH and saccH, the pattern of shifts, especially ${ }^{13} \mathrm{C}$ shifts can be readily categorized by the five-membered ring $\mathrm{C}^{\prime}$ s and the $(\mathrm{CH})_{4}$ group completing the sixmembered ring. Significant downfield shifts were observed for the $\mathrm{C} 2$ and $\mathrm{C} 8$ resonances of isa. In addition, the isaH imino ${ }^{1} \mathrm{H}$ signal disappeared (Table IV). These changes are consistent with binding of mercury to isa through the heterocyclic nitrogen, as suggested by the X-ray structure. The large effects are all on the five-membered ring except for that on $\mathrm{C7}$. The downfield shift for the $\mathrm{C} 7$ and $\mathrm{H} 7$ resonances of isa could be related to the proximity of the $\mathrm{Hg}$ to $\mathrm{C7}$. In (1) the shortest 


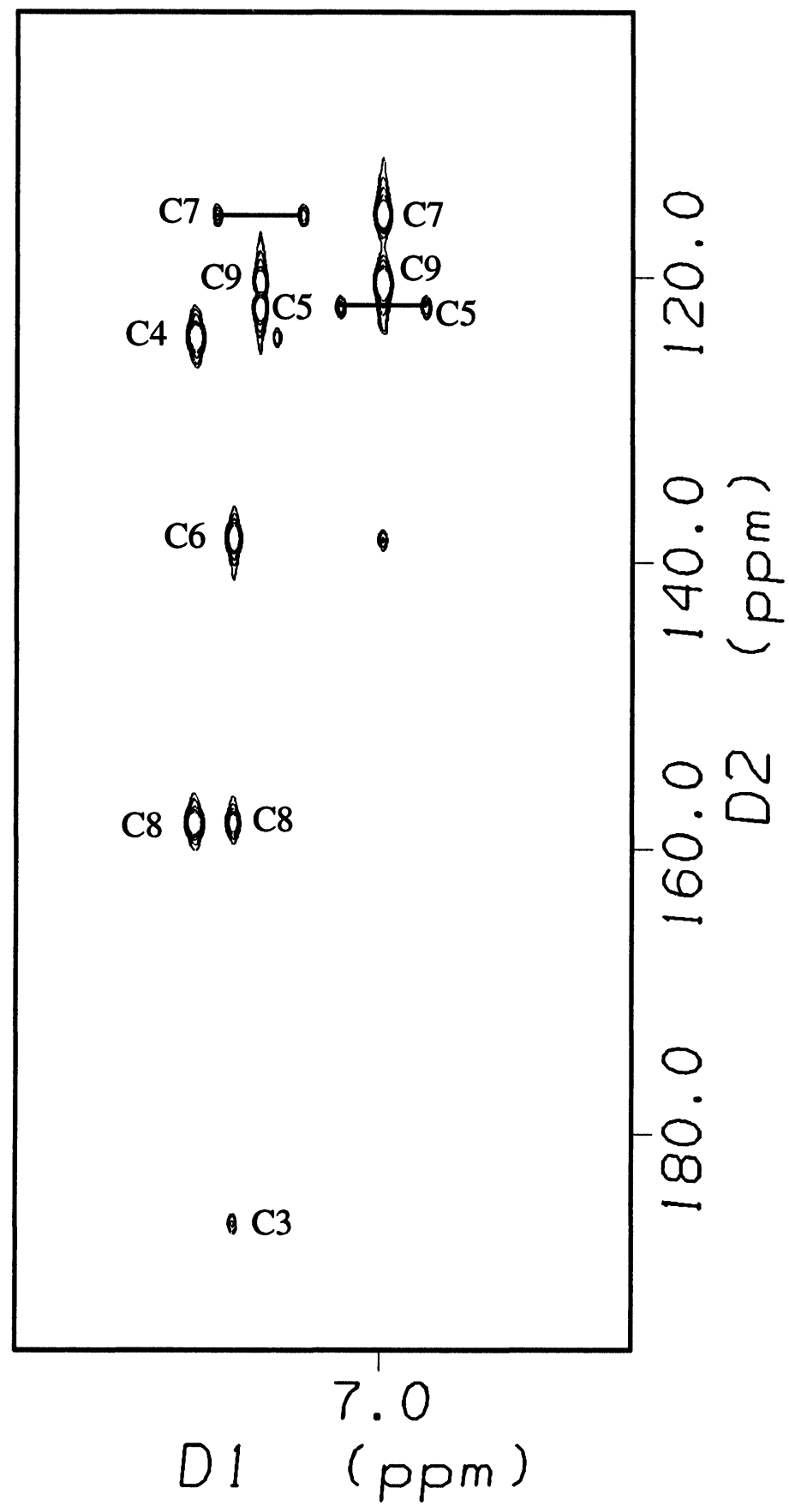

FIGURE 3. ${ }^{1} \mathrm{H}$-detected ${ }^{1} \mathrm{H}-{ }^{13} \mathrm{C}$ multiple-bond shift correlation (HMBC) spectrum of $\mathrm{Hg}(\text { isa })_{2}$ in DMSO- $d_{6}$. Incompletely suppressed "satellite" peaks from C5 and C7 are also present.

intramolecular nonbonded mercury contact to a $\mathrm{CH}$ is to $\mathrm{C} 7 \mathrm{H}$. No significant changes in ${ }^{1} \mathrm{H}$ and ${ }^{13} \mathrm{C}$ chemical shifts were observed for $\mathrm{C} 4, \mathrm{C} 5$ and $\mathrm{C} 6$ upon complexation, suggesting that in solution the aromatic rings are not involved in stacking interactions.

Protonation of saccharinate induced large upfield ( 6-7.2 ppm) and significant downfield shifts $(\sim 2.2-4.7 \mathrm{ppm})$ for the five-membered ring and $(\mathrm{CH})_{4}{ }^{13} \mathrm{C}$ resonances, respectively (Table IV). In addition, the ${ }^{1} \mathrm{H}$ resonances shifted downfield $(\sim 0.32-0.47 \mathrm{ppm})$ and a new signal in the imino proton region at $12.29 \mathrm{ppm}$ appeared. The same NMR pattern, although with smaller shift 
TABLE IV. ${ }^{1} \mathrm{H}$ and ${ }^{13} \mathrm{C}$ NMR Shift Assignments of isaH, $\mathrm{Hg}$ (isa) 2 (1), saccH, $\mathrm{Na}$ (sacc) and $\mathrm{Hg}(\mathrm{sacc})_{2}(3)$ in DMSO-d6a

\begin{tabular}{|c|c|c|c|c|c|c|}
\hline Assignment & ${ }^{1} H(1)^{b}$ & ${ }^{13} \mathrm{C}(1)^{c}$ & ${ }^{1} \mathrm{H}$ isaH $^{b}$ & ${ }^{13} \mathrm{C}$ isaH $^{c}$ & $\Delta \delta\left({ }^{13} C\right)^{d}$ & $\Delta \delta\left(^{1} H\right)^{d}$ \\
\hline $\begin{array}{c}\mathrm{N} 1 \mathrm{H} \\
\mathrm{C} 2 \\
\mathrm{C} 3 \\
\mathrm{C} 4 \mathrm{H} \\
\mathrm{C} 5 \mathrm{H} \\
\mathrm{C} 6 \mathrm{H} \\
\mathrm{C} 7 \mathrm{H} \\
\mathrm{C} 8 \\
\mathrm{C} 9\end{array}$ & $\begin{array}{l}7.47 \\
6.99 \\
7.59 \\
7.38\end{array}$ & $\begin{array}{l}163.8 \\
186.3 \\
124.3 \\
122.2 \\
138.4 \\
115.7 \\
158.3 \\
120.4\end{array}$ & $\begin{array}{l}7.51 \\
7.07 \\
7.59 \\
6.92\end{array}$ & $\begin{array}{l}159.3 \\
184.4 \\
124.7 \\
122.7 \\
138.3 \\
112.2 \\
150.7 \\
117.8\end{array}$ & $\begin{array}{c}4.5 \\
1.9 \\
-0.4 \\
-0.5 \\
0.1 \\
3.5 \\
7.6 \\
2.6\end{array}$ & $\begin{array}{c}-0.04 \\
-0.08 \\
0 \\
0.46\end{array}$ \\
\hline Assignment & $1_{H(3)^{b}}$ & ${ }^{13} \mathrm{C}(3)^{c}$ & ${ }^{1} \mathrm{H}$ sacch $^{b}$ & ${ }^{13} \mathrm{C} \mathrm{sacch} C$ & ${ }^{1} \mathrm{H}$ sacc $^{b}$ & ${ }^{13} \mathrm{C} \operatorname{sacc}^{c}$ \\
\hline $\begin{array}{c}\mathrm{N} 2 \mathrm{H} \\
\mathrm{C} 3 \\
\mathrm{C} 4 \mathrm{H} \\
\mathrm{C} 5 \mathrm{H} \\
\mathrm{C} 6 \mathrm{H} \\
\mathrm{C} 7 \mathrm{H} \\
\mathrm{C} 8 \\
\mathrm{C} 9\end{array}$ & $\begin{array}{l}8.00 \\
7.93 \\
7.99 \\
8.12\end{array}$ & $\begin{array}{l}163.8 \\
124.4 \\
134.0 \\
134.7 \\
120.7 \\
142.3 \\
128.8\end{array}$ & $\begin{array}{l}12.29 \\
8.09 \\
8.00 \\
8.06 \\
8.24\end{array}$ & $\begin{array}{l}160.7 \\
124.9 \\
134.8 \\
135.6 \\
121.2 \\
139.2 \\
127.5\end{array}$ & $\begin{array}{l}7.76 \\
7.68 \\
7.68 \\
7.77\end{array}$ & $\begin{array}{l}167.8 \\
122.4 \\
131.4 \\
130.9 \\
119.0 \\
145.2 \\
134.7\end{array}$ \\
\hline
\end{tabular}

$\bar{a}{ }^{1} \mathrm{H}$ and ${ }^{13} \mathrm{C}$ assignments were done by $2 \mathrm{D}$ NMR. $b_{\text {Relative to TMS. }} \bar{c}{ }^{13} \mathrm{C}$ shifts from the 1D NMR spectrum relative to TMS with DMSO-d $d_{6}$ peak as reference $(39.5 \mathrm{ppm}) . d_{\Delta \delta}=\delta_{(1)}-\delta_{\text {(isa) }}$

changes and without an imino ${ }^{1} \mathrm{H}$ resonance, were observed upon $\mathrm{Hg}$ interaction with sacc. All these facts are consistent with binding of the five-membered heterocyclic ring nitrogen to the $\mathrm{Hg}$, in agreement with the crystal structure of $\mathrm{Hg}(\mathrm{sacc})_{2} \cdot 27,28$

The shift pattern observed for $\mathrm{Hg}$ (isa) 2 compared to isaH and $\mathrm{Hg}(\mathrm{sacc})_{2}$ compared to saccH both can probably best be viewed as the result of a less powerful electron deficient center $\left(\mathrm{Hg}^{2+}\right)$ vs. a more powerful electron deficient center $\left(\mathrm{H}^{+}\right) .^{29-31}$ Thus, the effects of $\mathrm{Hg}^{2+}$ on the correctly ionized form of the free ligand, represented in this work by sacc ${ }^{-}$, is less than that of the $\mathrm{H}^{+}$. These effects are also evident in the binding of $\mathrm{Hg}(\mathrm{II})$ to thymidine, where the $\mathrm{Hg}^{2+}$ center appears to cause a downfield shift of the C4 relative to thymidine.2,3 Again, the best way to view the shifts is a smaller upfield shift in $\mathrm{C} 4$ of $\mathrm{N} 3$ deprotonated thymidine induced by $\mathrm{Hg}^{2+}$ than by $\mathrm{H}^{+}$.

In summary, we have established the structure of $\mathrm{Hg}$ (isa) ${ }_{2}$ in solution and solid state and have demonstrated that, as found previously for DNA, NMR spectroscopy is useful in assessing speciation of $\mathrm{Hg}(\mathrm{II})$ with other classes of molecules such as pharmaceuticals and food additives.

\section{ACKNOWLEDGMENTS}

We are grateful to DGICYT Ref.PB91-0806-C02-02 and the National Institutes of Health (Grant GM 29222 to L. G. M.) for financial support. We also wish to express our gratitude to Prof. V. Moreno, Universitat de Barcelona, Spain, for the $1 \mathrm{D}^{1} \mathrm{H}$ and ${ }^{13} \mathrm{C}$ NMR spectra of (1).

\section{REFERENCES}

(1) Katz, S. Biochim. Biophys. Acta 1963, 68, 240-253.

(2) Buncel, E.; Boone, C.; Joly, H.; Kumar, R.; Norris, A. R. J. Inorg. Biochem. 1985, 25, 61-73.

(3) Buncel, E.; Boone, C.; Joly, H. Inorg. Chim. Acta 1986, 125, 167-172.

(4) Frøystein, N. A.; Sletten, E. J. Am. Chem. Soc. 1994, 116, 3240-3250. 
(5) Young, P. R.; Nandi, U. S.; Kallenbach, N. R. Biochemistry 1982, 21, 62-66.

(6) Bauer, D. J.; Sadler, P. W. Nature (London) 1961, 190, 1167.

(7) Hassaan, A. M. A. Transition Metal Chemistry 1990, 15, 283.

(8) Patel, S. P.; Ray, A.; Patel, R. P. Synthesis and Reactivity in Inorganic and Metal-Organic Chemistry 1987, 17, 419-430.

(9) Khulbe, R. C.; Singh, R. P.; Bhoon, Y. K. Transition Metal Chemistry 1983, 8, 59.

(10) Garg, B. S.; Singh, R. P.; Garg, S. K. Indian J. Chem. 1991, 30A, 979.

(11) Davis, M. Advances in Heterocyclic Chemistry 1985, 38, 120.

(12) Muller, L. J. Am. Chem. Soc. 1979, 108, 2093.

(13) Bax, A.; Subramanian, S. J. Magn. Reson. 1986, 67, 565.

(14) Bax, A.; Summers, M. F. J. Am. Chem. Soc. 1986, 108, 2093.

(15) Goodgame, D. M. L.; Hill, S. P. W.; Williams, D. J. Polyhedron 1992, 11, 1507.

(16) Walker, N.; Stuart, D. Acta Crystallogr. 1983, A39, 158-166.

(17) MolEN, An Interactive Structure Solution Procedure; Enraf-Nonius: Delft, The Netherlands, 1990.

(18) Goodgame, D. M. L.; Khaled, A. M.; O'Mahoney, C. A.; Williams, D. J. J. Chem. Soc., Chem. Commun. 1990, 851.

(19) Goodgame, D. M. L.; Khaled, A. M.; O'Mahoney, C. A.; Williams, D. J. Polyhedron 1990, 14, 1765.

(20) Kosturko, L. D.; Folzer, C.; Stewart, R. F. Biochemistry 1974, 13, 3949.

(21) Palenik, G. J.; Koziol, A. E.; Katritzky, A. R.; Fan, W.-Q. J. Chem. Soc., Chem. Commun. 1990, 715-716.

(22) Palmer, M. H.; Blake, A. J.; Gould, R. O. Chemical Physics 1987, 115, 219-227.

(23) Goldschmidt, G. H.; Llewellyn, F. J. Acta Crystallogr. 1950, 3, 294-305.

(24) Soliman, E. M.; El-Roudi, A. M.; Hassaan, A. M. A.; Refaiy, S. A. Synth. React. Inorg. Met.Org. Chem. 1989, 19, 957-967.

(25) Goodgame, D. M. L.; Williams, D. J.; Winpenny, R. E. P. Angew. Chem. Int. Ed. Engl. 1987, 26, 1044.

(26) Hansen, P. E. Progress in NMR Spectroscopy 1981, 14, 175-296.

(27) Jovanovski, G.; Kamenar, B. Acta Crystallogr. A 1981, 37, C171.

(28) Kamenar, B.; Jovanovski, G.; Grdenic, D. Cryst. Struct. Commun. 1982, 11, 263-8.

(29) Marzilli, L. G.; Stewart, R. C.; Van Vuuren, C. P.; de Castro, B.; Caradonna, J. P. J. Am. Chem. Soc. 1978, 100, 3967-8.

(30) Marzilli, L. G.; de Castro, B.; Caradonna, J. P.; Stewart, R. C.; van Vuuren, C. P. J. Am. Chem. Soc. 1980, 102, 916-24.

(31) Marzilli, L. G.; de Castro, B.; Solorzano, C. J. Am. Chem. Soc. 1982, 104, 461-6.

Received: October 13, 1994 - Accepted: November 8, 1994 - Received in revised camera-ready format: November 25, 1994 